Portland State University

PDXScholar

$11-1987$

\title{
The Impact of Weather on Kingbird Foraging Behavior
}

Michael T. Murphy

Portland State University, murphym@pdx.edu

Follow this and additional works at: https://pdxscholar.library.pdx.edu/bio_fac

Part of the Biology Commons, and the Ornithology Commons Let us know how access to this document benefits you.

\section{Citation Details}

Murphy, Michael T., "The Impact of Weather on Kingbird Foraging Behavior" (1987). Biology Faculty Publications and Presentations. 82.

https://pdxscholar.library.pdx.edu/bio_fac/82

This Article is brought to you for free and open access. It has been accepted for inclusion in Biology Faculty Publications and Presentations by an authorized administrator of PDXScholar. Please contact us if we can make this document more accessible: pdxscholar@pdx.edu. 


\title{
THE IMPACT OF WEATHER ON KINGBIRD FORAGING BEHAVIOR ${ }^{1}$
}

\author{
Michael T. MuRPHY ${ }^{2}$ \\ Museum of Natural History, The University of Kansas, Lawrence, KS 66045
}

\begin{abstract}
Foraging data on Eastern Kingbirds (Tyrannus tyrannus) were collected during the early breeding season in eastern Kansas to test the hypothesis that foraging rate and other aspects of foraging behavior vary with weather. Foraging characteristics of five additional kingbird species were also examined to assess Fitzpatrick's (1980) generalization that kingbirds (Tyrannus spp.) are aerial hawking specialists. In Eastern Kingbirds, total foraging rate was independent of air temperature, cloud cover, wind speed, and time of day, but the rate of aerial hawking varied directly with air temperature and inversely with cloud cover (both $P<0.05$ ). Effects of the two variables were additive. The percentage of foraging movements that were aerial hawks also increased with temperature and declined with cloud cover, and, hover-gleaning and perch-to-ground sallying were observed mainly during cloudy weather. Sally (i.e., foraging flight) distance correlated directly with perch height and air temperature, and large insects were captured almost exclusively in long upward or horizontal flights. I interpret these data to indicate that foraging behavior and the capture of large, flying insects depends on weather because of how it affects the activity of insect prey. Foraging data on kingbirds support Fitzpatrick's generalization, but the relative use of aerial hawking varies considerably among species. Resident Tropical Kingbirds ( $T$. melancholicus) are the most specialized foragers, whereas the migrant and widely distributed Eastern Kingbird appears to be the most generalized. Certain habitats also appear to favor the use of particular foraging methods (e.g., outward striking in grasslands, and perch-to-ground sallying in drier, open habitats).
\end{abstract}

Key words: Aerial hawking; foraging behavior; prey capture; Tyrannus tyrannus; weather.

\section{INTRODUCTION}

Avian ecologists have quantified tyrant flycatcher foraging behavior for many purposes ranging from the study of morphology (Karr and James 1975, Traylor and Fitzpatrick 1982), resource use and community structure (Beaver and Baldwin 1975, Eckhardt 1979, Blancher and Robertson 1984, Sherry 1984), phylogenetic relationships (Fitzpatrick 1980), to analyses of migratory behavior (Verbeek 1975a). Analyses of stomach contents have shown that diets are diverse, but the main flycatcher prey are the Hymenoptera, Coleoptera, Orthoptera, Hemiptera, and Diptera (Bent 1942, Dick and Rising 1965, Hespenheide 1971, Beaver and Baldwin 1975, Sherry 1984). An unexplored, yet important area of flycatcher foraging ecology concerns the impact of weather on foraging patterns. In view of the dependence between body temperature and capacity for flight in most insects (Heinrich 1981, Kingsolver 1983a), it seems logical that proxi-

\footnotetext{
${ }^{1}$ Received 11 September 1986. Final acceptance 13 May 1987.

2 Present address: Department of Life Sciences, Indiana State University, Terre Haute, IN 47809.
}

mate weather conditions should be a primary determinant of insect flight activity, food availability and therefore foraging behavior of flycatchers. However, with only rare exception (Davies 1977, Foreman 1978), all flycatcher foraging studies to date have explicitly avoided collecting data during poor weather, and as a result, there is a critical shortage of information on how tyrannid foraging varies with weather.

This gap in knowledge is significant for at least two reasons. From the perspective of understanding the evolution of flycatcher reproductive patterns it is essential to determine what factors influence foraging success. In the other large group of aerial foragers, swallows and swifts, foraging and reproductive success vary with weather because of the strong dependence between insect flight activity and meteorological conditions. Low air temperatures, precipitation, high cloud cover, and wind all reduce the availability of flying insects (Bryant 1973; Hespenheide 1975; Davies 1977; Visscher and Seeley 1982; Kingsolver 1983a, 1983b; Jones 1987). The accepted view is that life histories of species that exploit the "aerial plankton" have been shaped largely by high, but short-term temporal and spatial vari- 
ation in insect abundance (Lack and Lack 1951; Bryant 1973; O’Connor 1977, 1979; Jones 1987). Likewise, hawkers such as flycatchers depend on insect movement for prey detection and capture (e.g., Davies 1977), and Murphy (1983) suggested that weather has also been an integral factor in the evolution of temperate-zone breeding flycatcher life histories. Poor weather negatively affects flycatcher reproductive success (Davies 1977, O'Connor and Morgan 1982, Murphy 1983), yet except for Davies' (1977) study, the link between weather, foraging, and prey capture is not established in flycatchers (but see Mahan 1964).

Second, weather's impact on flycatcher foraging behavior is relevant for interspecific studies of either niche relationships (Beaver and Baldwin 1975, Verbeek 1975b, Holmes et al. 1978), or assessment of foraging specialization (Fitzpatrick 1980). Measuring niche overlap using only "fair-weather" studies may be misleading since diet and foraging behavior are expected to diversify when food becomes scarce (Pyke et al. 1977), which is most likely to occur when poor weather depresses insect activity. Since competition is most likely when food is least abundant, quantification of community relationships and foraging plasticity in flycatchers should not be restricted to fair weather.

In this report I quantify foraging patterns of Eastern Kingbirds (Tyrannus tyrannus) in eastern Kansas to address the issues raised above. I will test predictions that short-term changes in weather are the primary determinants of variability in kingbird foraging behavior and success (Murphy 1983). I will also assess Fitzpatrick's (1980) classification of the genus Tyrannus as aerial hawking specialists by evaluating their degree of behavioral flexibility through (1) intraand interspecific comparisons of kingbird foraging, and (2) by examining the consistency of Eastern Kingbird foraging as weather changes.

\section{METHODS}

I collected data on Eastern Kingbirds in May and early June of 1981, 1982, and 1983 in Douglas County, eastern Kansas (site description in Murphy 1986). Foraging behaviors were recorded opportunistically while kingbird nests were located early in the season. I limited my observations to pre-egg stage birds to control for seasonal changes in food abundance (Murphy 1986) and for variation in energy needs due to breeding activities.
Most observations were of individuals in pastures and recently abandoned fields where small shrubs, fence posts, and fence lines were the main perch substrates.

Terminology follows Fitzpatrick (1980). Sallying refers to the approach flight preceding a prey capture attempt. All foraging moves were initiated by a flight from a perch, and included aerial hawking (direct flights to capture a single, flying insect), outward striking (prey are snatched from vegetation following a rapid, direct flight), outward hover-gleaning (prey are located and picked from vegetation following a brief hovering flight), and perch-to-ground sallying (prey are picked from the ground after a direct flight).

Foraging birds were observed from $\geq 50 \mathrm{~m}$ using binoculars under all weather conditions except rain. Observations were recorded vocally with a hand-held tape recorder and later were transcribed. Upon sighting a foraging bird (indicated by previous foraging attempts, and alert posture), I waited for it to initiate a new foraging sequence and then recorded time of day, and all further perch heights, foraging movements, perch changes without a prey capture attempt being made, sally distances, and flight trajectories (above, below or level with the perch). Horizontal flights occurred within about $15^{\circ}$ of the plane parallel with the ground surface. Foraging period duration was also timed to the nearest second with a stop watch. Observations were continued for as long as a bird was in sight up to a maximum of $15 \mathrm{~min}$. I ended all observations at $15 \mathrm{~min}$ to avoid overrepresenting foraging under any specific environmental condition (e.g., a local insect emergence).

Within the study area fences and fence posts were abundant, were of uniform height and spacing, and were frequently used by kingbirds. I therefore estimated sally distances and perch heights to the nearest foot and half-foot, respectively, by referring to fence lines. I later converted distance to meters. Except in the case of ralge unsecis I was unabie to determine whether capture attempts were successful. However, kingbirds had to kill large insects by beating them against a perch, which allowed me to record their capture.

At the end of each foraging period, I recorded air temperature using a Schulteis fast reading thermometer (shielded from sun and wind) and wind speed at breast height $(1.4 \mathrm{~m})$ with a Sims hand-held cup anemometer. The stall speed of 
the anemometer was about $8 \mathrm{~km} / \mathrm{hr}$, hence, I was only able to measure winds that exceeded $8 \mathrm{~km} /$ $\mathrm{hr}$. The wind measurements no doubt failed to precisely reflect the actual convective microenvironment of the bird, but I believe they accurately portrayed general environmental conditions. Cloud cover was estimated by classifying sky conditions into five categories of percentage cover (i.e., $1=0$ to $20 \%, 2=21$ to $40 \%, \ldots$, $5=81$ to $100 \%$ ).

\section{PREDICTIONS AND ANALYSIS}

Insect flight activity increases with increasing air temperature, clearing sky conditions, and decreasing wind speeds (see references above). Assuming energy intake is sensitive to insect activity, I expected the following patterns to emerge. First, total foraging and hawking rate would increase with air temperature, and decline with increasing cloud cover and wind speed. Second, assuming perches were selected to maximize encounters with prey, I predicted an increase in perch height with increasing air temperature, decreasing cloud cover, and wind speed. Third, Leck (1971) proposed that long sally distances in kingbirds reflect good foraging conditions. Long flights presumably indicate greater availability and selectivity of prey. I therefore expected sally distance to increase with air temperature, and decline with increasing cloud cover and wind speeds. Optimal foraging theory (Pyke et al. 1977) predicts also that diet diversity, and in this case foraging diversity, will increase as the expected rate of energy intake declines. Hence, kingbirds should switch from being foraging specialists to generalists as weather deteriorates.

I excluded all foraging bouts in which birds were observed for $<3 \mathrm{~min}$. For the remainder I calculated foraging rate (foraging moves $/ \mathrm{min}$ ), hawking rate (number of aerial hawks/min), mean and median perch height, sally distance, and the percentage of foraging movements as aerial hawks (minimum of three foraging movements required for inclusion). Percentages were arcsine transformed. Univariate comparisons of behavior to weather were made using least-squares linear regression and correlation analysis. Multivariate relationships were further examined using step-wise multiple regression (BMDP2R; Dixon 1981). I also grouped birds according to weather conditions and calculated foraging diversity with respect to weather using a standard measure, $J$ (Eckhardt 1979). $J$ takes into account both the diversity and equitability of use of different foraging categories, and is defined as $H^{\prime} / H^{\prime}{ }_{\text {max }}$, where $H^{\prime}=-\Sigma p_{i} \log p_{i}$, and $p_{i}$ is the proportion of each foraging behavior. $H_{\text {max }}^{\prime}$ is the maximum diversity possible given $n$ foraging categories, where $p_{i}=1 / n$ for all $i$. $J$ varies between 0 and 1 , the two extreme values representing a specialist using one behavior (0) and a generalist using all foraging methods equally (1).

\section{RESULTS}

\section{GENERAL FORAGING CHARACTERISTICS}

Breeding Eastern Kingbirds foraged as "sit-andwait" predators since $85 \%(n=477)$ of searches ending in a foraging flight. Of these, aerial hawking accounted for $50.0 \%$ of all foraging moves, followed by outward strikes (39.9\%), hover-gleans $(8.1 \%)$, and perch-to-ground sallies (2.0\%). Other foraging behaviors observed infrequently at other times (e.g., during rain or the emergence of aquatic insects) included gleaning of lepidopteran larvae from trees by upward striking, surface gleaning from water, and multiple captures of aerial prey by hovering during a single flight. The latter behavior, described also by Blancher and Robertson (1985), involved many consecutive hover-gleans while the bird moved in a slow flight over grass covered fields. Frugivory on mulberries (Morus rubra; Stapanian 1982) was also common later in the season when fruit was included in both adult and nestling diets (M. T. Murphy, pers. observ.).

Perch height averaged $1.3 \mathrm{~m}(\mathrm{SD}=1.53, n=$ 49 ; range $=0.3$ to $9.1 \mathrm{~m}$ ) and mean sally distance was $2.9 \mathrm{~m}(\mathrm{SD}=1.58 \mathrm{~m}, n=49$; range $=0.9$ to $7.6 \mathrm{~m}$ ). The median sally distance of $2.1 \mathrm{~m}$ was shorter than the $3.7 \mathrm{~m}$ reported by Via (1979). Kingbirds returned to the same perch used to initiate prey captures $53.5 \%$ of the time $(n=$ $325)$, similar to Via's reported value $(48.8 \%$; $t$-test for percentages, $t=0.7, P \gg 0.05$ ). However, sally distance influenced the probability of perch reuse since median distance for individuals reusing perches was $1.5 \mathrm{~m}$, compared to $2.5 \mathrm{~m}$ for new perches (median test, $\mathrm{G}=15.6, \mathrm{df}=1$, $P<0.01$; Zar 1974). Sally distance also varied with flight trajectory. Downward, horizontal, and upward flights accounted for about 59, 32, and $9 \%(n=376)$ of all attempted prey captures, respectively. Median (and mean) sally distance for level $(2.3 \mathrm{~m}[2.9 \mathrm{~m}])$ and upward flights $(2.4$ $\mathrm{m}[3.8 \mathrm{~m}]$ ) did not differ significantly (median 

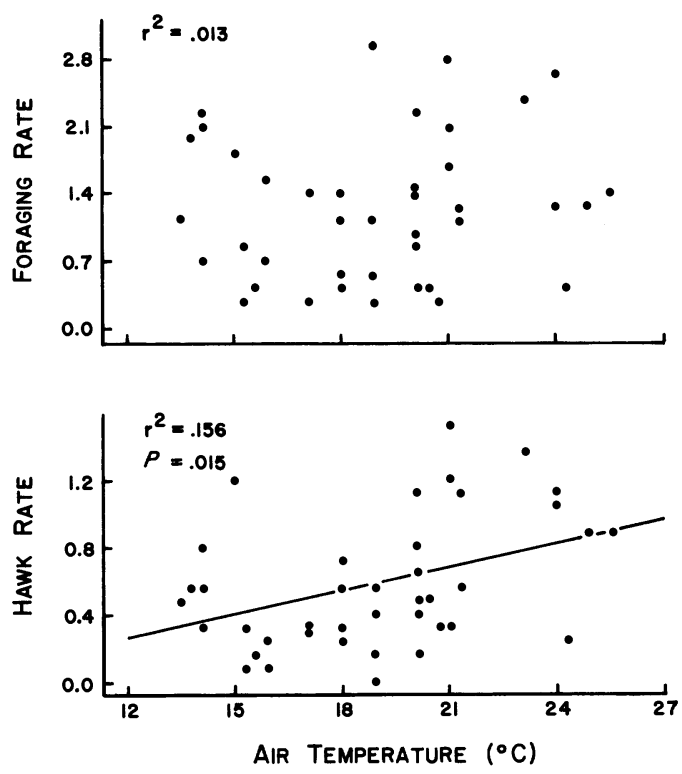

FIGURE 1. Foraging rate (number of moves/min) as a function of ambient air temperature for (a) all foraging tactics, and, (b) just hawking behaviors (number of aerial hawks/min) for Eastern Kingbirds from Douglas County, Kansas.

test, $\mathrm{G}=0.47$, $\mathrm{df}=1$ ), but the median of their combined distributions was longer than for downward flights $(1.9 \mathrm{~m}[2.3 \mathrm{~m}] ; \mathrm{G}=5.80$, $\mathrm{df}=1, P<0.025)$. Large insects were also more likely to be captured in upward $(6.0 \%$ of all foraging moves) and level (3.4\%) flights compared to downward flights $(0.4 \%)\left(\chi^{2}=6.96, \mathrm{df}=2\right.$, $P<0.025)$.

\section{FORAGING RATE}

Foraging rates varied widely ( $\bar{x}=1.2$ moves/ min, $\mathrm{SD}=0.76, n=40$ ), but essentially none of the variability was related to air temperature $(r=$ 0.110 ; Fig. 1a), wind speed $(r=-0.033)$, cloud cover $(r=0.027)$ or time of day $(r=-0.048)$. Further restriction of the analysis to timed observations $\geq 5 \mathrm{~min}$, or $\geq 7 \mathrm{~min}$ did not affect the results.

I examined hawking rate separately because kingbirds (Tyrannus spp.) preferentially capture insects by aerial hawking (Fitzpatrick 1980). Hawking rate increased with air temperature $(r=$ $0.395, P<0.02$; Fig. 1b) and decreased with cloud cover $(r=-0.325, P<0.05$; Fig. 2). Hawking rate did not vary with wind speed $(r=$ 0.072 ), but tended to decline as the day pro$\operatorname{gressed}(r=-0.235, P=0.15)$. Stepwise multiple

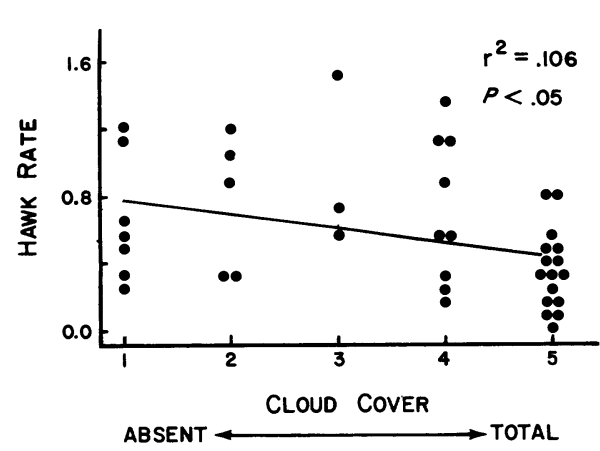

FIGURE 2. Hawking rate (number of hawks/min) vs. cloud cover for Eastern Kingbirds from Douglas County, Kansas.

regression indicated that effects of temperature and cloud cover were additive, and that despite uncontrolled variation in absolute insect abundance among years (Murphy 1986), recent past weather, and differences among birds in hunger level and body condition, the two-variable model of air temperature and cloud cover explained a quarter of the variation in hawking rate $(r=$ $0.501, \mathrm{df}=2,37, P<0.01)$. The partial correlation of both temperature and cloud cover were significant $(P<0.05)$ when effects of the other variable were controlled statistically. Adding time of day to the model explained little additional variation $(r=0.537, \mathrm{df}=3,36, P<0.01)$.

\section{PERCH HEIGHT AND SALLY DISTANCE}

Perch height did not vary with air temperature $(r=0.238)$, wind speed $(r=-0.134)$, cloud cover $(r=-0.050)$, or time of day $(r=-0.092)$. Sally distance also varied independently of wind speed $(r=-0.049)$, cloud cover $(r=-0.042)$, and time of day $(r=-0.171)$, but did tend to vary directly with temperature $(r=0.250, P=0.12, n=40)$. As is common in flycatching birds (Pinkowski 1977, Greig-Smith 1983, Moreno 1984), perch height and sally distance were correlated $(r=$ $0.441, n=40, P<0.01$ ), and even higher so if birds that perched in trees were excluded $(r=$ $0.623, n=36, P<0.001)$. I thus reexamined sally distance in relation to temperature and perch height using multiple regression analysis. The two-variable model was significant for birds that did not use trees as perches $(r=0.683, \mathrm{df}=2$, $33, P<0.01$ ), but the partial correlation of sally distance and temperature was not $(r=0.250)$. A plot of residual sally distance (effects of perch 


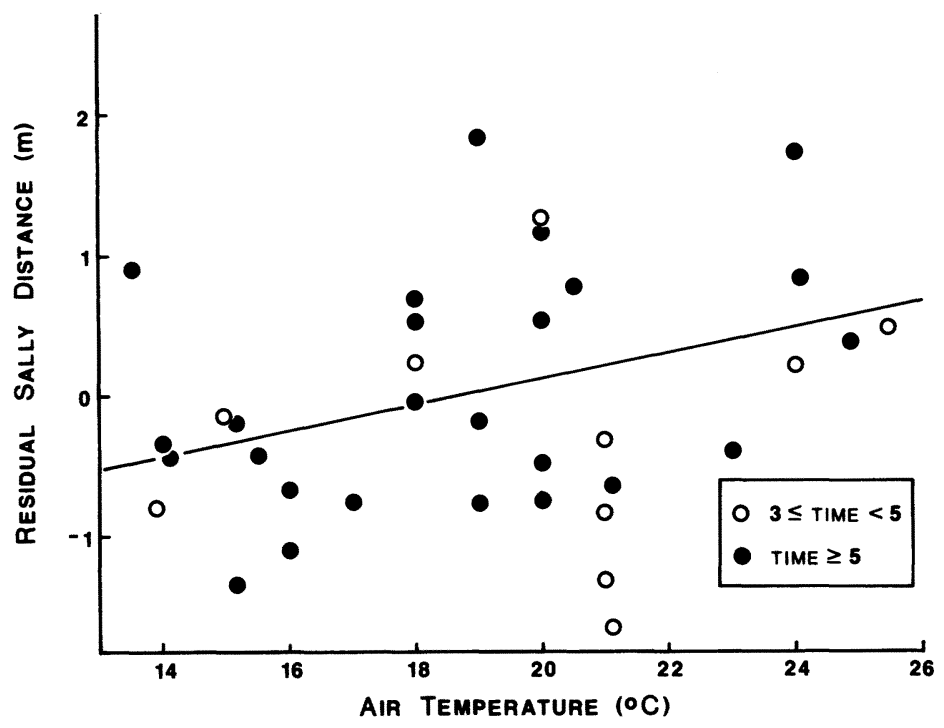

FIGURE 3. Residual sally distance (perch height effects removed) vs. ambient air temperature for Eastern Kingbirds from Douglas County, Kansas. Each point is based on the mean of all sallies from individual foraging bouts. Open circles are for bouts lasting $\geq 3 \mathrm{~min}$, but $<5 \mathrm{~min}$, whereas closed circles are for bouts lasting $\geq 5$ min. The solid line is the least-squares linear regression of residual distance vs. temperature for all points except the two low values near $21^{\circ} \mathrm{C}(P=0.03$; see text $)$.

height removed) vs. temperature (Fig. 3) suggested that the nonsignificant partial correlation of sally distance with temperature was due to two low values near $21^{\circ} \mathrm{C}$. I observed both birds for just over $3 \mathrm{~min}$, and it is possible that the short observation periods resulted in spurious measurements. Residual sally distance and temperature correlated significantly when either the latter two points were excluded $(r=0.380, \mathrm{df}=$ $33, P=0.03$; Fig. 3 ), or if the analysis was limited to foraging episodes lasting $\geq 5 \mathrm{~min}(r=0.391$, $\mathrm{df}=24, P=0.054$; Fig. 3).

\section{FORAGING DIVERSITY}

The fact that hawking rate, but not total foraging rate, varied significantly with air temperature and cloud cover suggested that the frequency of use of different behaviors varied with weather. Indeed, this was the case (Table 1). At low air temperatures kingbirds hawked infrequently and relied mainly on outward striking from vegetation. At the highest air temperatures they hawked about $70 \%$ of the time. Cloudy skies also produced a sharp drop in the frequency of hawking. Interestingly, perch-to-ground sallying and hovergleaning were almost never observed except under cloudy conditions. Using the percentage of each bird's foraging movements that were aerial hawks, I found that the percentage of hawks varied directly with air temperature $(r=0.378, \mathrm{P}=$ $0.02)$, inversely with cloud cover $(r=-0.408$, $P=0.01)$, but was independent of wind $(r=$ 0.053 ). Temperature and sky conditions together accounted for about $27 \%$ of the variation in hawking percentage $(r=0.523, \mathrm{df}=2,34, P<$ $0.01 ; \%$ hawks $=27.0+1.83$ [TEMP] 4.53[SKY]). Temperature and cloud cover were not related $(r=-0.129, P>0.40)$, hence both variables contributed significantly $(P<0.05)$ to the two-variable regression model. Foraging diversity varied substantially over the range of air temperatures and sky conditions, mainly due to the high diversities observed at intermediate values of both environmental variables. Foraging diversity was greatest between 15 and $18^{\circ} \mathrm{C}$, and at about $50 \%$ sky cover.

\section{INTRA- AND INTERSPECIFIC COMPARISONS}

I have attempted to summarize each study of kingbird foraging (Table 2) within Fitzpatrick's framework so as to facilitate comparisons. With the exception of Tatschl's data (which reported substrates from which prey were taken instead of foraging movements), aerial foraging (hawking plus sallying) was reported as the usual foraging method for all species, accounting for between 
TABLE 1. Variation in foraging behavior and foraging diversity $(J)$ by Eastern Kingbirds as air temperature $\left({ }^{\circ} \mathrm{C}\right)$ and cloud cover varied during foraging.

\begin{tabular}{|c|c|c|c|c|c|c|}
\hline & \multicolumn{4}{|c|}{ Foraging behaviors ${ }^{a}$} & \multirow[b]{2}{*}{$n^{\mathrm{b}}$} & \multirow[b]{2}{*}{$J$} \\
\hline & Hawk & Strike & Hover & P-to-G & & \\
\hline \multicolumn{7}{|c|}{ Temperature } \\
\hline $\begin{array}{l}13-14 \\
15-16 \\
17-18 \\
19-20 \\
21-22 \\
23-24 \\
25-26\end{array}$ & $\begin{array}{l}0.358 \\
0.361 \\
0.488 \\
0.493 \\
0.553 \\
0.671 \\
0.714\end{array}$ & $\begin{array}{l}0.566 \\
0.556 \\
0.512 \\
0.400 \\
0.404 \\
0.205 \\
0.190\end{array}$ & $\begin{array}{l}0.056 \\
0.000 \\
0.000 \\
0.093 \\
0.042 \\
0.096 \\
0.095\end{array}$ & $\begin{array}{l}0.019 \\
0.083 \\
0.000 \\
0.013 \\
0.000 \\
0.027 \\
0.000\end{array}$ & $\begin{array}{l}53 \\
36 \\
43 \\
75 \\
47 \\
73 \\
21\end{array}$ & $\begin{array}{l}0.668 \\
0.820 \\
1.000 \\
0.716 \\
0.753 \\
0.659 \\
0.710\end{array}$ \\
\hline \multicolumn{7}{|l|}{ Sky cover } \\
\hline $\begin{array}{l}1 \text { (clear) } \\
2 \\
3 \\
4 \\
5 \text { (total) }\end{array}$ & $\begin{array}{l}0.676 \\
0.644 \\
0.633 \\
0.506 \\
0.342\end{array}$ & $\begin{array}{l}0.309 \\
0.311 \\
0.366 \\
0.376 \\
0.526\end{array}$ & $\begin{array}{l}0.015 \\
0.044 \\
0.000 \\
0.082 \\
0.096\end{array}$ & $\begin{array}{l}0.000 \\
0.000 \\
0.000 \\
0.035 \\
0.035\end{array}$ & $\begin{array}{r}68 \\
45 \\
30 \\
85 \\
114\end{array}$ & $\begin{array}{l}0.629 \\
0.713 \\
0.947 \\
0.746 \\
0.756\end{array}$ \\
\hline
\end{tabular}

a Values are the proportion of each foraging behavior. Hawk = aerial hawk; Strike = outward strike; Hover = hover- gleaning; P-to-G = perch-toground sally.

Sample size refers to number of prey capture attempts.

70 and $90 \%$ of a species' foraging movements. The exception was my study of Eastern Kingbirds in Kansas where aerial hawking accounted for only $50 \%$ of prey capture attempts. This differs greatly from the hawking percentage of about $90 \%$ in the two studies of Eastern Kingbirds from West Virginia and Ontario. Although it is important to realize that Tatschl's classification method differed from the other studies, note that Eastern Kingbirds farther west in Kansas foraged from vegetation even more than individuals in my study.

Considerable variability also exists both within and among species in the use of other foraging methods. Perch-to-ground sallying, for example, was relatively uncommon in all species except Western ( $T$. verticalis) and Cassin's kingbirds ( $T$. vociferans). Sallying, the successive capture of several flying insects in one foraging flight, was observed in at least four species, but was only moderately common in one population of Western Kingbirds. Gray Kingbirds (T. dominicensis) foraged from vegetation about a quarter of the time, whereas Tropical Kingbirds ( $T$. melancholicus) appear to be the most behaviorally specialized forager. They relied on aerial hawking nearly $95 \%$ of the time. Although conclusions about Scissor-tailed Flycatchers (T. forficatus) are limited because the data are not strictly comparable, scissortails appear to capture most insects directly from vegetation.

\section{DISCUSSION}

My purpose in measuring the impact of weather on kingbird foraging was twofold. I first sought to test predictions arising from Murphy's (1983) suggestion that Eastern Kingbird life history evolution has been driven mainly by the influence of short-term, weather-induced changes in food availability on reproductive success. Support for this hypothesis was obtained by showing that kingbird foraging patterns, and in particular attempted prey capture rates, varied with weather in the same fashion as insect availability (see references above). Second, and from a more methodological standpoint, I attempted to determine if avoiding poor weather while collecting data might lead to underestimates of foraging breadth. At least for open-country flycatchers, "fair-weather" studies do appear to underestimate behavioral flexibility.

\section{THE IMPACT OF WEATHER}

Although total foraging rate was unaffected by the measured meteorological variables, weather did influence foraging behavior and very probably had a marked effect on total energy intake. For example, the frequency and rate of aerial hawking rose with increasing air temperature and declining cloud cover. Perch-to-ground sallying and hover-gleaning increased mainly when skies were clouded over (Table 1), indicating a shift 
TABLE 2. Foraging mode profiles of six species of kingbirds. Data are presented as percentages of the total number $(n)$ of foraging moves. T indicates trace use $(<1 \%)$. Numbers 1 through 9 under species headings refer to literature sources. Brackets enclose methods that were not distinguished in the original sources.

\begin{tabular}{|c|c|c|c|c|c|c|c|c|c|c|c|c|}
\hline \multirow{3}{*}{$\begin{array}{l}\text { Foraging } \\
\text { method }^{\mathbf{b}}\end{array}$} & \multicolumn{12}{|c|}{ Species $^{\mathrm{a}}$} \\
\hline & \multicolumn{4}{|c|}{ EKB } & \multicolumn{2}{|c|}{ WKB } & \multicolumn{2}{|c|}{ CKB } & \multicolumn{2}{|c|}{ STF } & \multirow{2}{*}{$\begin{array}{c}\text { TKB } \\
8\end{array}$} & \multirow{2}{*}{$\begin{array}{c}\text { GKB } \\
9\end{array}$} \\
\hline & 1 & 2 & 3 & 4 & 1 & 5 & 5 & 6 & 1 & 7 & & \\
\hline Hawking & 17 & 92 & 86 & 50 & 26 & 58 & 70 & 84 & 8 & & 94 & 71 \\
\hline O-Strike & 81 & 8 & 1 & 40 & 59 & - & - & 8 & 86 & 88 & 2 & 26 \\
\hline $\begin{array}{l}\text { Hover } \\
\text { P-G-Sally }\end{array}$ & $\begin{array}{r}81 \\
2\end{array}$ & $\gamma$ & $\begin{array}{r}12 \\
1\end{array}$ & $\begin{array}{l}8 \\
2\end{array}$ & 15 & $\begin{array}{r}7 \\
17\end{array}$ & $\begin{array}{r}1 \\
22\end{array}$ & $\begin{array}{l}0 \\
9\end{array}$ & 6 & & 1 & 3 \\
\hline Sally & - & - & - & $\mathrm{T}$ & - & 18 & 7 & - & - & 2 & - & - \\
\hline Gr-Hop & - & - & - & - & - & - & - & - & - & 10 & - & - \\
\hline Fruit & - & - & - & $\mathrm{T}$ & - & - & - & - & - & $\mathrm{T}$ & 3 & $\mathrm{~T}$ \\
\hline$n$ & 247 & 68 & 2,443 & 406 & 352 & 162 & 124 & 183 & 67 & 2,718 & 425 & 34 \\
\hline
\end{tabular}

a EKB = Eastern Kingbird; WKB = Western Kingbird; CKB = Cassin's Kingbird; STF = Scissor-tailed Flycatcher; TKB = Tropical Kingbird; GKB = Gray Kingbird.

b Hawking = aerial hawking; O-Strike = outward striking; Hover = hover-gleaning; P-G-Sally = perch-to-ground sallying; Sally = >1 prey capture/ foraging flight; Gr-Hop $=>1$ prey capture/flight to the ground; Fruit $=$ frugivory.

Sources: 1-Tatschl 1973; 2-Via 1979; 3-Blancher and Robertson 1985; 4-this study; 5-Goldberg 1979; 6-Landres and MacMahan 1980; 7-Foreman 1978; 8-Fitzpatrick 1980; 9-Ricklefs and Cox 1977.

from passive to active foraging. Insects commonly use the sun to bask and raise body temperature to the levels necessary for flight (Kingsolver 1983a, 1983b), and I suggest that when skies were cloudy kingbirds were forced to actively search for prey because few insects were flying. Unlike the other variables wind had no measurable influence on hawking rate, or any other foraging trait. Foreman (1978) showed that foraging rate and success of Scissor-tailed Flycatchers varied directly with temperature and inversely with cloud cover, but he found also that strong winds depressed foraging success. The unimportance of wind in my study probably stems from a lack of strong winds during measurements.

Leck (1971) suggested and Davies (1977) showed that long flights by aerial hawkers indicated attempts to capture large prey. I therefore predicted and verified that sally distance would vary directly with temperature. Moreover, most captures of large insects were by long horizontal, but especially upward flights. I suspect that higher air temperature increased insect flight activity and permitted kingbirds to pursue larger, and more abundant flying prey. Unlike the other foraging variables perch height was independent of weather. This lack of significance, and the generally low perch heights that I recorded (compare to Foreman 1978, Goldberg 1979, Via 1979, Blancher and Robertson 1984), probably stem from the low perch diversity in the study area. As a result of the use of low perches, sally dis- tances also tended to be short in comparison to other kingbirds (see references above).

As indicated by the diversity index, $J$, kingbirds exhibited high behavioral flexibility in their mode of prey attack (compare to Eckhardt 1979). However, foraging diversity did not change with weather as expected. Optimality models (Pyke et al. 1977) yielded the prediction that foraging diversity would increase linearly as the expected rate of energy intake fell, i.e., as air temperatures dropped and cloud cover increased. Instead, foraging diversity peaked at intermediate weather conditions. I interpret these, and the previously discussed patterns, as indicating that limits to insect flight during poor weather were so severe that kingbirds had to almost abandon aerial hawking under such conditions. They switched to striking and hover-gleaning insects from vegetation using short, downward flights. As weather improved insects began to fly and kingbirds increased the frequency of hawking. However, flying insects were probably not yet abundant enough to permit abandoning foraging from vegetation. As a result, at intermediate conditions kingbirds foraged as extreme generalists. With further improvements in weather, kingbirds switched to mainly aerial hawking and the use of longer flights to capture large insects. Foraging diversity therefore tends to be minimal at extreme environmental conditions, but for different reasons.

The switch from outward striking to aerial hawking probably has a major impact on parental feeding capacity. Flycatchers feed their young 
with individual, whole prey (Bent 1942; pers. observ.), and hawking results usually in the capture of large prey in a single flight. On the other hand, outward striking from vegetation yields few large prey items, and involves high levels of activity. Hence, during poor weather adults might maintain a positive energy balance by making numerous, short feeding flights on a concentrated supply of small prey. But, it is doubtful whether parents feeding a brood of young at a distant nest can use this tactic to keep young fed adequately. Given that large insect flight activity declines at all levels of the air space when temperature falls (Jones 1987), the poor reproductive success of kingbirds during inclement weather seems best explained as an inability by the parents to capture the larger insect food of the young (Murphy 1983). Mahan (1964) showed that Eastern Phoebes (Sayornis phoebe) decrease food delivery rates to nests when wind speeds increase and light intensity falls. But, he also found that delivery rate increased as air temperature fell. I suggest this was because phoebes were unable to capture large insects, and like kingbirds, switched to foraging on small prey when air temperatures were low.

A question that now arises is how much of the difference in the use of aerial hawking between kingbirds in Kansas and eastern North America (Table 2) is due to weather. By assuming "fairweather" conditions (air temperature of $25^{\circ} \mathrm{C}$ and clear sky), and using the multiple regression equation relating hawking percentage to temperature and cloud cover (see above), I estimate that Eastern Kingbirds hawk for insects about $70 \%$ of the time during good foraging conditions in Kansas. I believe the remaining difference is due to habitat. Most of my observations were made in pastures and grasslands, which may favor the use of nonhawking foraging methods (especially outward striking from vegetation). The main insect prey of kingbirds in Kansas are Hymenoptera, Orthoptera, and Coleoptera (Dick and Rising 1965), which tend to be concentrated at the air-vegetation interface. Insect density is probably very high in this region, making foraging profitable at or just above the grass surface.

Tatschl (1973) reported an even greater reliance on foraging from vegetation (81\%). Although his figure appears somewhat high, our data concur and suggest that living in grasslands favors using vegetation as a foraging substrate. Furthermore, Fitzpatrick (1980) stated that a South American grassland specialist, Alectrurus tricolor, "uniquely combines aerial hawking with outward striking." But, A. tricolor and Eastern Kingbirds in my study aerial hawk and outwardstrike at virtually identical frequencies. Presumably this is related to similarity of habitat.

\section{KINGBIRDS: SPECIALIST OR GENERALIST FORAGERS?}

Fitzpatrick (1980) arbitrarily designated that specialist foragers use one prey capture technique for greater than $50 \%$ of all attacks on prey. Thus, despite differences among kingbirds in whether or not they forage from the ground or vegetation (Table 2), all kingbirds studied are aerial hawking specialists. The only uncertainty is over the Scissor-tailed Flycatcher, which may concentrate much of its foraging from vegetation. This would not be surprising given that Eastern Kingbirds appear to increase the use of striking from vegetation in similar habitats (see also Blancher and Robertson 1985). The importance of habitat in establishing differences among species in " $\mathrm{mi}$ nor" foraging specializations is further suggested by the frequent use of perch-to-ground sallying by Western and Cassin's kingbirds (Table 2). Because of the availability of bare ground in drier portions of western North America, perch-toground sallying is a possible foraging technique. It is therefore not surprising that Bent (1942) reported that ground-foraging beetles (Carabidae and Cicindelidae) were more common in the diets of Western Kingbirds than any other tyrant.

Of the species listed in Table 2, only the Tropical Kingbird is a resident, and it appears to be the most specialized forager. Sherry (1984) previously noted greater specialization among residents compared to migrants in other tyrants. He suggested that temporal variation in the diversity and abundance of available prey for migrants, especially in physically stressful grassland habitats, was much greater than for tropical tyrannids (see Wiens and Rotenberry 1979 for insect data). Greater variability in insect availability forces migrants to be opportunistic foragers, as the Eastern Kingbird data demonstrate. I suggest further that the level of foraging specializations within migrants is a function of the habitat and climatic diversity encountered over their geographic range. Present information (Table 2) can not be used to test this idea, but the data are suggestive. Eastern Kingbirds have the widest distribution in temperate latitudes of any kingbird, and they appear to be the most variable 
foragers, especially if frugivory is included (Stapanian 1982; E. S. Morton, pers. comm.).

"Specialist" is a relative term, and as applied by Fitzpatrick (1980), does not separate tyrants using similar foraging behaviors adequately. Nonetheless, it is a useful concept for examining relationships between foraging behavior and traits such as reproduction (Murphy, unpubl.) or migration (Verbeek 1975a). To examine such questions it is necessary to determine how species respond behaviorally to variation in the environmental parameters affecting prey abundance. For temperate zone kingbirds I believe this is weather, and secondarily habitat. Expectations are that specialists will show little variation irforaging behavior as weather changes, but generalists like the Eastern Kingbird will show high foraging flexibility.

\section{ACKNOWLEDGMENTS}

Field work was supported by funds from the Alexander E. Bergstrom Research Award of the Northeastern Birc Banding Association, the Frank M. Chapman Fund of the American Museum of Natural History, and by ? Summer Fellowship from the University of Kansas Graduate School. NSF grant BSR 830065 to Dr. George S. Bakken of Indiana State University provided me with funds while I prepared the final version of this manuscript. Comments by Peter Stacey, an anonymous reviewer, and especially Tom Sherry greatly improved the manuscript.

\section{LITERATURE CITED}

Beaver, D. L., AND P. H. Baldwin. 1975. Ecological overlap and the problem of competition and sympatry in the Western and Hammond's flycatchers. Condor 77:1-13.

BENT, A. C. 1942. Life histories of North American flycatchers, larks, swallows, and their allies. U.S. Natl. Mus. Bull. 179.

Blancher, P. J., AND R. J. Robertson. 1984. Resource use by sympatric kingbirds. Condor 86 : 305-313.

$\rightarrow$ BlanCher, P. J., AND R. J. Robertson. 1985. A comparison of Eastern Kingbird breeding biology in lakeshore and upland habitats. Can. J. Zool. 63: 2305-2312.

Bryant, D. M. 1973. The factors influencing the selection of food by the House Martin (Delichon urbica [L.]). J. Anim. Ecol. 42:539-564. $\rightarrow$ Davies, N. B. 1977. Prey selection and the search $\rightarrow$
strategy of the Spotted Flycatcher (Muscicapa striata): a field study on optimal foraging. Anim. Behav. 25:1016-1033.

Dick, J. A., AND J. D. Rising. 1965. A comparison of foods eaten by Eastern Kingbirds and Western Kingbirds in Kansas. Bull. Kansas Ornithol. Soc. $16: 23-24$.
Dixon, W. J. 1981. BMDP-81. Univ. of California Press, Berkeley.

ECKHARDT, R. C. 1979. The adaptive syndromes of two guilds of insectivorous birds in the Colorado Rocky Mountains. Ecol. Monogr. 49:129-149.

FITZPATRICK, J. W. 1980. Foraging behavior of Neotropical tyrant flycatchers. Condor 82:43-57.

ForemAN, L. D. 1978. Activity patterns and foraging behavior of the Scissor-tailed Flycatcher (Muscivora forficata). Ph.D.diss., Texas A\&M University, College Station.

GoldBERG, N. H. 1979. Behavioral flexibility and foraging strategies in Cassin's and Western kingbirds (Tyrannus vociferans and $T$. verticalis) breeding sympatrically in riparian habitats in central Arizona. Ph.D.diss., Univ. of Illinois at Urbana, Champaign.

Greig-SMITH, P. W. 1983. Use of perches as vantage points during foraging by male and female Stonechats Saxicola torquata. Behaviour 86:215-236.

HeINRICH, B. 1981. Insect thermoregulation. John H. Wiley and Sons, New York.

$\rightarrow$ Hespenheide, H. A. 1971. Food preference and the extent of overlap in some insectivorous birds, with special reference to the Tyrannidae. Ibis 113:5972.

Hespenheide, H. A. 1975. Selective predation by two swifts and a swallow in Central America. Ibis 117: 82-99.

Holmes, R. T., T. W. Sherry, and S. E. BenNett. 1978. Diurnal and individual variability in the foraging behavior of American Redstarts (Setophaga ruticilla). Oecologia (Berl.) 36:141-149.

JONES, G. 1987. Time and energy constraints during incubation in free-living swallows (Hirundo rustica): an experimental study using precision electronic balances. J. Anim. Ecol. 56:229-245.

KARR, J. R., AND F. C. JAMES. 1975. Eco-morphological configurations and convergent evolution in species and communities, p. 258-291. In M. L. Cody and J. M. Diamond [eds.], Ecology and evolution of communities. Belknap Press, Cambridge, MA.

Kingsolver, J. G. 1983a. Thermoregulation and flight in Colias butterflies: elevational patterns and mechanistic limitations. Ecology 64:534-545.

KINGSOLVER, J. G. 1983b. Ecological significance of flight activity in Colias butterflies: implications for reproductive strategy and population structure. Ecology 64:546-551.

LACK, D., AND E. LACK. 1951. The breeding biology of the Swift, Apus apus. Ibis 93: 501-548.

LANDRes, P. B., AND J. A. MacMahon. 1980. Guilds and community organization: analysis of an oak woodland avifauna in Sonora, Mexico. Auk 97: 351-365.

LECK, C. F. 1971. Some spatial and temporal dimensions of kingbird foraging-flights. Wilson Bull. 83:310-311.

MaHAN, H. D. 1964. The effect of the environment on growth, development, and temperature regulation in nestling Eastern Phoebes. Ph.D.diss., Michigan State Univ., East Lansing.

MoRENO, J. 1984. Search strategies of Wheatears 
(Oenanthe oenanthe) and Stonechats (Saxicola torquata): adaptive variation in perch height, search time, sally distance and inter-perch move length. J. Anim. Ecol. 53:147-159.

$\rightarrow$ MurPhy, M. T. 1983. Clutch size in the Eastern Kingbird: factors affecting nestling survival. Auk 100:326-334.

MurPhy, M. T. 1986. Temporal components of reproductive variability in Eastern Kingbirds ( $T y$ rannus tyrannus). Ecology 67:1483-1492.

O’CONNOR, R. J. 1977. Growth strategies of nestling passerines. Living Bird 16:209-238.

O'ConNor, R. J. 1979. Egg weights and brood reduction in the European Swift (Apus apus). Condor 81:133-145.

$\rightarrow$ O'ConNor, R. J., AND R. A. Morgan. 1982. Some effects of weather conditions on the breeding of the Spotted Flycatcher Muscicapa striata in Britain. Bird Study 29:41-48.

$\rightarrow$ PINKowsKI, B. C. 1977. Foraging behavior of the Eastern Bluebird. Wilson Bull. 89:404-414.

Pyke, G. H., H. R. Pulliam, and E. L. Charnov. 1977. Optimal foraging theory: a selective review of theory and tests. Q. Rev. Biol. 52:137-154.

$\rightarrow$ Ricklefs, R. E., AND G. W. Cox. 1977. Morphological similarity and ecological overlap among passerine birds on St. Kitts, British West Indies. Oikos 29:60-66.

Sherry, T. W. 1984. Comparative dietary ecology of sympatric insectivorous Neotropical flycatchers (Tyrannidae). Ecol. Monogr. 54:313-338.
Stapanian, M. A. 1982. Evolution of fruiting strategies among fleshy-fruited plant species of eastern Kansas. Ecology 63:1422-1431.

TATSCHL, J. L. 1973. Niche exploitation among three closely related flycatchers in Kansas. Ph.D.diss., Kansas State Univ., Manhattan.

Traylor, M. A., JR., AND J. W. FitzPatrick. 1982. A survey of the tyrant flycatchers. Living Bird 19: $7-50$.

$\rightarrow$ VERBEEK, N.A.M. 1975a. Northern wintering of flycatchers and residency of Black Phoebes in California. Auk 92:737-749.

VERBEEK, N.A.M. 1975b. Comparative feeding behavior of three coexisting tyrannid flycatchers. Wilson Bull. 87:231-240.

VIA, J. W. 1979. Foraging tactics of flycatchers in southwestern Virginia, p. 191-202. In J. G. Dickson, R. N. Connor, R. R. Fleet, J. A. Jackson and J. C. Kroll [eds.], The role of insectivorous birds in forest ecosystems. Academic Press, New York.

Visscher, P. K., AND T. D. Seeley. 1982. Foraging strategy of honeybee colonies in a temperate deciduous forest. Ecology 63:1790-1801.

Wiens, J. A., AND J. T. RotenberRY. 1979. Diet niche relationships among North American grassland and shrub-steppe birds. Oecologia (Berl.) 42:253-293.

ZAR, J. H. 1974. Biostatistical analysis. Prentice-Hall, Englewood Cliffs, NJ. 